9. Khimicheskii sostav rossiiskikh pishchevykh produktov: Spravochnye tablitsy soderzhaniia osnovnikh pishchevykh veshchestv $i$ energeticheskoi tsennosti pishchevykh produktov/ pod red. Akademika AMN SSR A.A. Pokrovskogo. - M.: Pishchevaia Promyshlennost, 1976.

10. Khimicheskii sostav pishchevykh produktov: Spravochnik/ pod red. prof., d-ra tekhn. nauk I.M. Skurikhina i prof. $d$-ra med. nauk M.N. Volgareva. - M.: VO «Agropromizdat», 1987.

11. D.Shpaar, K.Ginapp, D.Dreger, A.Zakharenko, S.Kalenska ta in.. Kukurudza. Viroshchuvannia, zbirannia, konservuvannia i vikoristannia / Pid zagalnoiu redaktsiciu D.Shpaara. - K.: Alfa-steviia LTD - 2009. - 396 s.

12. Kapreliants L.V., Iorgachova K. G. Funktsionalni produkti. Odesa: Druk, $2003-312$ s.

13. Merko I.T., Morhun V.O. Naukovi osnovy i tekhnolohiia pererobky zerna. - Odesa: Druk, 2001. - S. 59-65.

14. Tyrsin Iu.A., Poverin A.D. Tekhnologiia produktov funktsionalnogo pitannia $v$ forme krupianykh kash bystrogo prigotovleniia s rastitelnymi dobavkami // Khranenie i pererabotka selkhozsyria// 2003. - № 4. - S. 79-81.

15. Aiusheva O. G., Tsybikova G. Ts., Naidakova Ts. A. i dr. Novye produkti funktsionalnogo naznacheniia $s$ ispolzovaniem lekarstvennnykh rastenii // Materialy IV Mezhdunar. nauchn.-tekhnich. konferentsii "Pishcha. Ekologiia. Chelovek. Moskva, 2001. - S. 444.

16. Guliaev V.N. Tekhnologiia krupianykh kontsentratov / V.N. Guliaev, T.S. Zakharenko, V.I. Kondratev i t.d.-M.: Agropromizdat, 1989. - 200 s.

17. Troitskaia E. Ia. Vtorichnye materialnye resursy pishchevykh otraslei i puti ikh ispolzovaniia $v$ obshchestvennom pitanii// Tezisy dokladov nauchnoi konferentsii «Problemi industrializatsii obshchestvennogo pitannia strany». - Kharkov, 1989. - S. 212-213

18. Shatniuk L.N., Stepanova E.N., Spirichev V.B. Puti povysheniia vitaminnoi i mineralnoi tsennosgi pishchevykh kontsentratov// Moskva: AgooNIIITZIPP. - 1987. - Vsh. 9. - S. 37.

19. Tkachev R.Ia. Konservirovanie sakharnoi kukuruzy.// Moskva: Izdatelstvo «Pishchevaia promyshlennost». $1966-104 \mathrm{~s}$.

20. Volper I.N. Produkty iz kukuruzy //Moskva: Pishchepromizdat. - $1963-92$ s.

21. Електронний ресурс. Режим доступу: http://www.ukragroconsult.com

22. Електронний ресурс. Режим достуny: http://www.maisadour-semences.fr

23. Електронний ресурс. Режим доступy: https://www.apk-inform.com/ru

24. Електронний ресурс. Режим доступy: http://www.ukrstat.gov.ual

Надійшла 11.05.2018. До друку 05.06.2018 Адреса для переписки:

ОНАХТ, вул. Канатна, 112, м. Одеса, 65039, bunyak.e.v@gmail.com

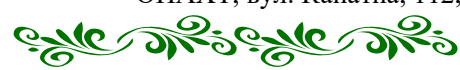

УДК 664.661:664.696.3:005.336.1

О.В. ЛАКІЗА, канд. техн. наук, доцент, К.П. МАСЛІКОВА, канд. біол. наук, доцент

М.В. ІЩЕНКО, магістр

Дніпровський державний аграрно-економічний університет

\title{
ЕФЕКТИВНІСТЬ ЗАСТОСУВАННЯ ВИСОКОБІЛКОВИХ ФУНКЦІОНАЛЬНИХ ПРОДУКТІВ У ВИРОБНИЦТВІ БУЛОЧОК
}

\begin{abstract}
Анотація
Хлібобулочні вироби є важливим продуктом харчування для більшості населення України. Потреба в хлібобулочних виробах притаманна людям будь-якого віку, соиіального статусу $і$ рівня доходів. Хлібопекарська галузь покликана забезпечувати споживачів країни цими життєво значущими продуктами харчування в необхідних обсягах, асортименті та якості.

В даний час в світі велика увага приділяється збагаченню хлібобулочних виробів різними корисними речовинами, що додають їм лікувальні та профілактичні властивості. Лікувальний і профілактичний ефект від вживання дієтичних хлібобулочних виробів забезпечується або введенням в рецептуру необхідних додаткових компонентів, або вилученням небажаних, або зміною технології їх приготування. Однією з ключових умов сучасного виробництва функціональних хлібобулочних виробів є пошук і використання нових компонентів рецептурного складу. Функиіональні продукти - ие харчові продукти, що є частиною звичайного раціону, які крім поживних властивостей мають здатність позитивно впливати на ті чи інші функиії організму людини.

У статті розглянуто сучасні напрями розширення асортименту хлібобулочних виробів з оздоровчими властивостями. 3 метою урізноманітнення продукції хлібопекарського виробництва функціонального призначення було запропоновано введення в рецептуру булочок високобілкових функціональних продуктів, а саме льняного шроту та шроту з насіння гарбуза. Відомо, щзо насіння льону та гарбуза містить у своєму складі всі ессенціальні амінокислоти.

На основі експериментальних досліджень розроблено рецептури булочок з додаванням лляного $і$ гарбузового шроту, які дають змогу одержати збагачені білком булочки відповідної якості. Проведено органолептичну оцінку якості булочок з різним вмістом шротів, побудовано профілограми на основі бальної оцінки. Зроблено висновок стосовно впливу концентрації шротів на пористість та вологість готових виробів. Обрано оптимальну концентрацію льняного шроту та шроту з насіння гарбуза в рецептурі булочок.
\end{abstract}

Ключові слова: льняний шрот, гарбузовий шрот, високобілкові продукти, булочки, органолептичні показники, вологість, пористість 
Лікувальний i профілактичний ефект від вживання дієтичних хлібобулочних виробів забезпечується або введенням в рецептуру необхідних додаткових компонентів, або вилученням небажаних, або зміною технології їх виготовлення. Однією з ключових умов сучасного виробництва функціональних хлібобулочних виробів $€$ пошук і використання нових компонентів рецептурного складу.

Функціональні продукти - це харчові продукти, що $є$ частиною звичайного раціону, які крім поживних властивостей мають здатність позитивно впливати на ті чи інші функції організму людини [1]. Однак, виконання всіх функцій в організмі людини залежить від правильності організації харчування. В раціональному харчуванні людини визначальним фактором $\epsilon$ наявність всіх основних корисних речовин, які вона вживає в їжу. До таких, передусім, належать білки, жири, вуглеводи, макро- та мікроелементи, незамінні амінокислоти, поліненасичені жирні кислоти, природні антиоксиданти, харчові волокна та багато інших речовин.

Їжа являється джерелом енергії, яка необхідна організму людини як для процесу обміну речовин,

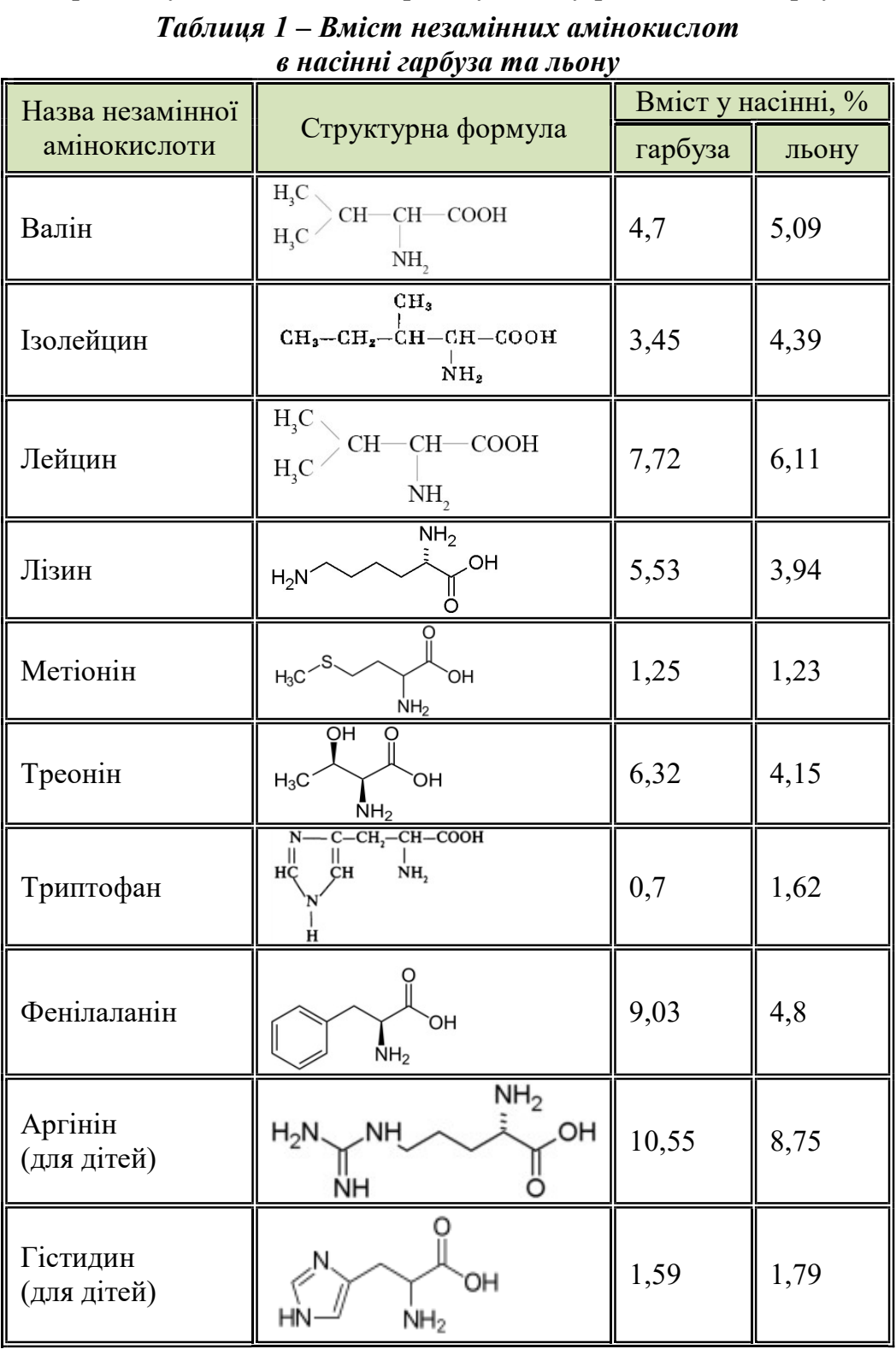


Першим етапом досліджень є розробка рецептури булочок $з$ додаванням льняного і гарбузового шроту. До складу контрольного зразка додавали наступні інгредієнти: борошно пшеничне першого сорту, дріжджі хлібопекарські пресовані, меланж, сіль кухонну, цукор білий кристалічний, молоко сухе знежирене, ванілін, висівки. До складу дослідних булочок додавали наступні компоненти: борошно пшеничне першого сорту, дріжджі хлібопекарські пресовані, меланж, сіль кухонну, цукор білий кристалічний, молоко сухе знежирене, ванілін, висівки, a 6
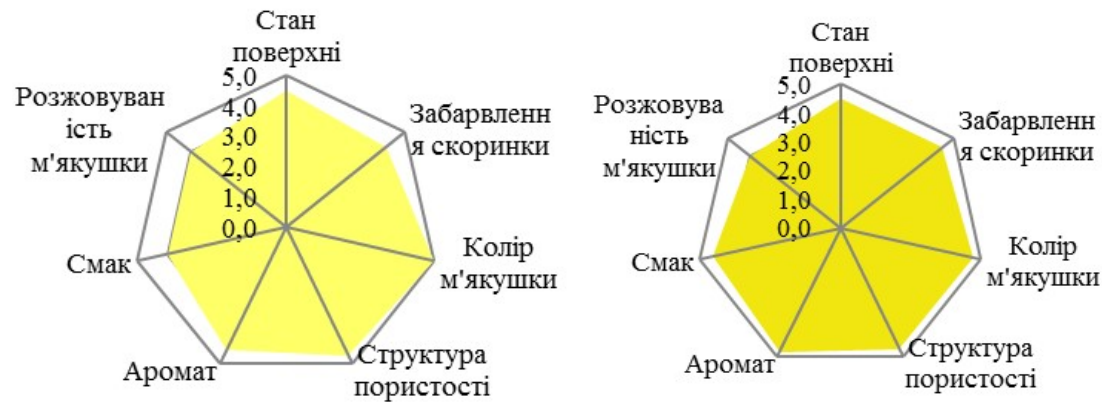

$\Gamma$

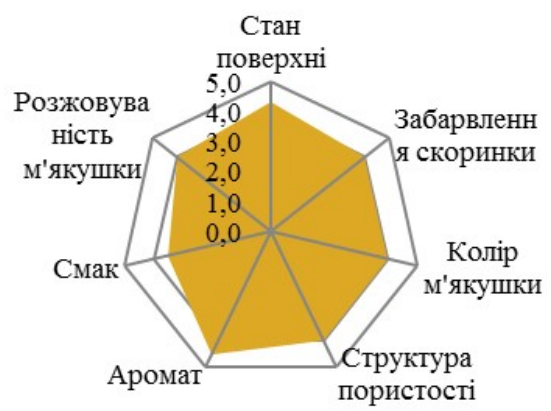

a
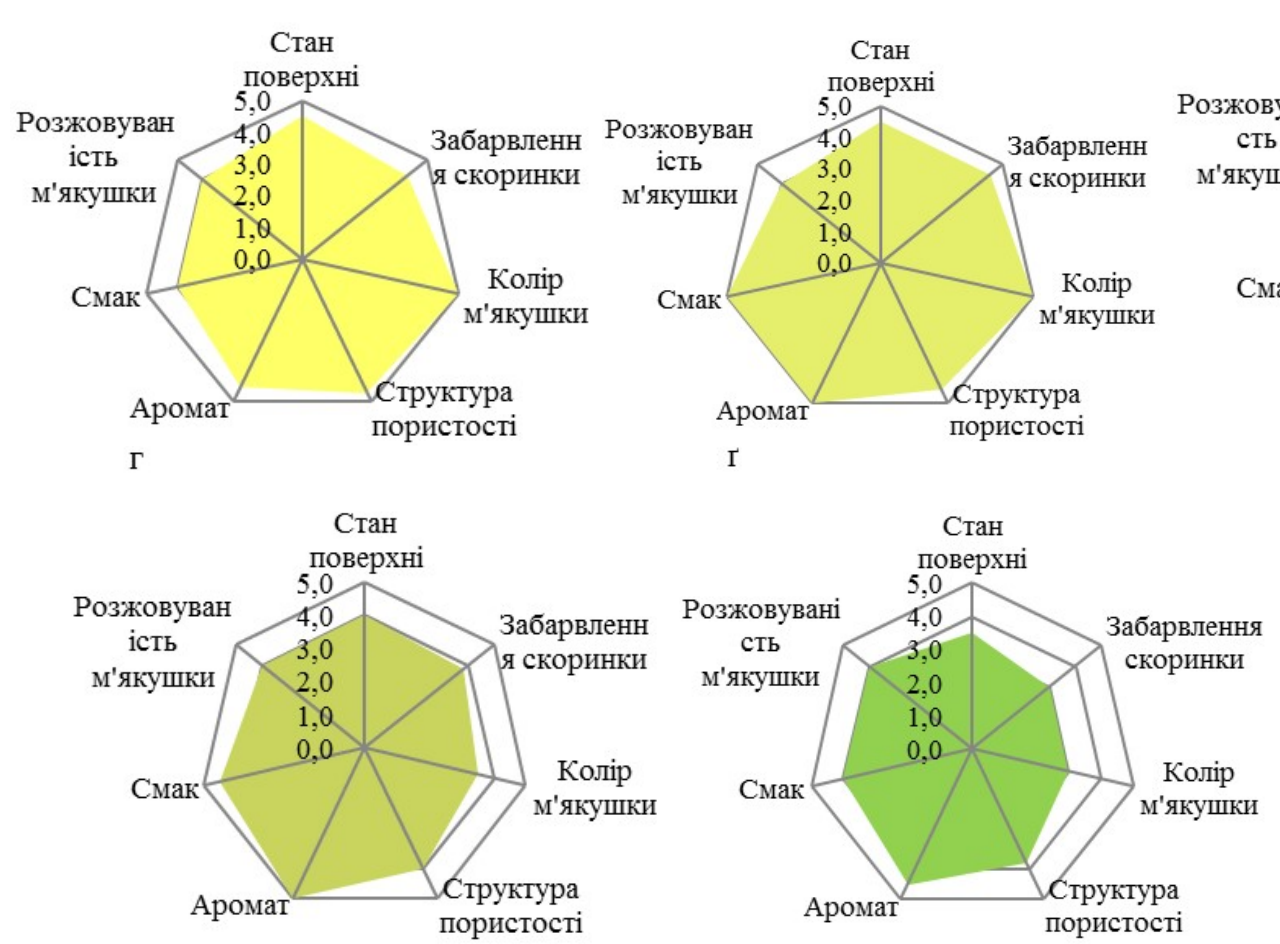

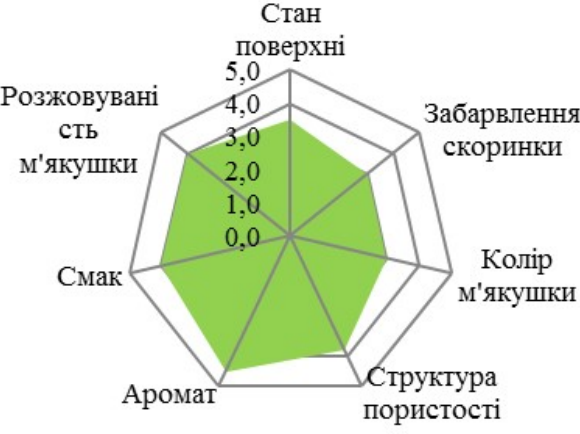

шрот харчовий із насіння гарбуза, шрот харчовий із насіння льону якість яких відповідає вимогам нормативно-технічної документації. Тісто готували опарним способом із введенням на стадії замісу тіста шроту насіння льону та гарбуза.

Визначення якості булочок $з$ додаванням гарбузового та льняного шроту проводили за допомогою органолептичного оцінювання пробних лабораторних випічок $[7,8]$. Результати бальної оцінки якості виробів представлені у вигляді профілограм на рис. 1 та 2.

B

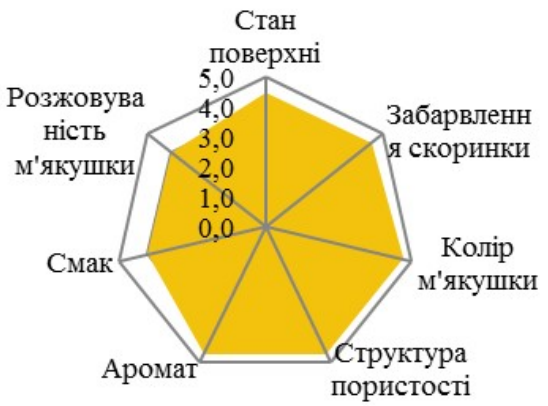

Pис. 1 - Бальна оцінка якості булочок залежно від вмісту льняного шроту:

а-контроль,

$$
\begin{aligned}
& \sigma-3 \%, \\
& \boldsymbol{b}-5 \%, \\
& z-7 \%, \\
& \boldsymbol{t}-10 \%
\end{aligned}
$$

Рис. 2 - Бальна оцінка якості булочок залежно від вмісту гарбузового ироту:

$\boldsymbol{a}-$ контроль
б-3\%,
$\boldsymbol{6}-\mathbf{5 \%}$,
$2-7 \%$,
$\boldsymbol{\tau}-10 \%$


Вологість, \%

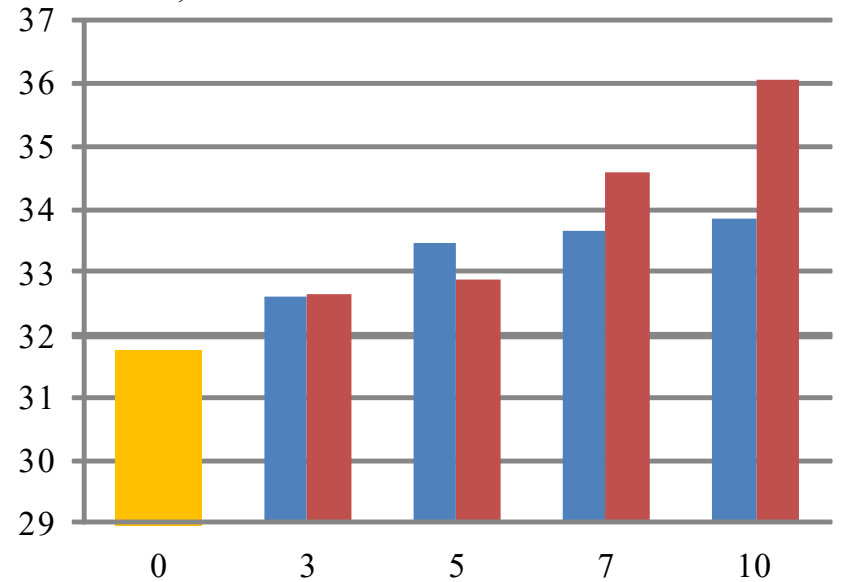

$\begin{array}{lllll}0 & 3 & 5 & 7 & 10\end{array}$

Контроль В Віст гарбузо вого та льняного шроту, \%

Вологість зразків 3 додаванням гарбузового шроту

Рис. 3 - Порівняльний аналіз вологості зразків 3 різним вмістом гарбузового та льняного шроту

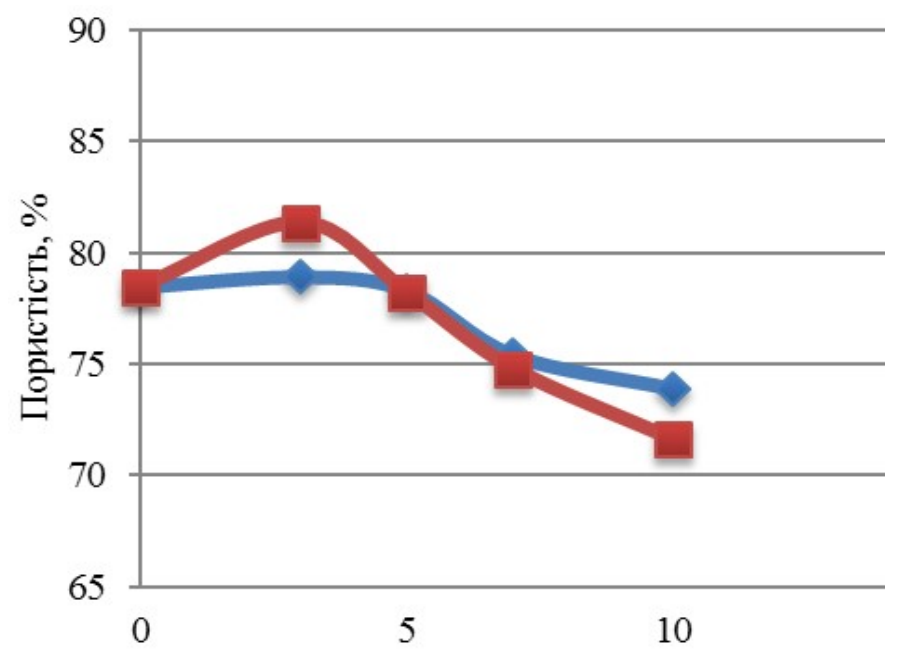

Вміст гарбузового та льняного шротів, \%

$\leadsto$ Пористість зразків 3 додаванням гарбузового шроту

- Пористість зразків 3 додаванням льняного шроту

Рис. 4 - Порівняльний аналіз пористості зразків 3 різним вмістом гарбузового та льняного шроту

Дані, представлені на рис. 1 показують, що додавання льняного шроту у кількості 3-5 \% до маси борошна позитивно впливає на органолептичні показники булочок: забарвлення скоринки, смак та аромат. При подальшому збільшенні вмісту шроту органолептичні показники мали тенденцію до погіршення.
Результати дослідження, які відображені на рис. 2, свідчать про те, що в порівнянні з контрольним зразком застосування гарбузового шроту у кількості 3-5 \% дозволяє покращити органолептичні показники готових виробів. Додавання гарбузового шроту у більшій кількості негативно впливає на забарвлення скоринки, колір м'якушки та структуру пористості.

Як свідчать дані зображені на рис. 3, збільшення концентрації льняного шроту до 5 \% забезпечує значення вологості м'якушки не вище 34 \% як регламентує нормативно-технічна докментація [8,9], а подальше збільшення вмісту шроту призводить до різкого підвищення вологості. В той час як при додаванні гарбузового шроту від 3 до 10 \% відбувається поступове зростання вологості м'якушки.

Порівняльний аналіз пористості зразків (рис.4) показує, що концентрація льняного та гарбузового шротів в межах 3-5 \% дозволяє забезпечити необхідний рівень пористості м'якушки - не менше $70 \%$ згідно вимог НТД $[8,10]$.

Результати експериментальних досліджень дозволили визначити оптимальну концентрацію 3-5\% льняного та гарбузового шротів в рецептурі булочок, яка дозволяє зберегти необхідний рівень органолептичних та фізико-хімічних показників готових виробів.

\section{Висновки}

1. Лікувальний і профілактичний ефект від вживання дієтичних хлібобулочних виробів може забезпечуватися наступними діями: введенням в рецептуру необхідних додаткових компонентів, вилученням небажаних компонентів, зміною технології виготовлення виробів. Однією з ключових умов сучасного виробництва функціональних хлібобулочних виробів є пошук і використання нових компонентів рецептурного складу.

2. 3 метою розширення асортименту продукції хлібопекарського виробництва функціонального призначення було запропоновано введення в рецептуру булочок високобілкових функціональних продуктів, а саме льняного шроту та шроту 3 насіння гарбуза, які збагачені білками і містять у своєму складі всі ессенціальні амінокислоти.

3. Розроблено склад булочок $з$ додаванням льняного і гарбузового шроту. Проведено органолептичну оцінку якості булочок з різним вмістом шротів, побудовано профілограми на основі бальної оцінки. Зроблено висновок стосовно впливу концентрації шротів на пористість та вологість готових виробів. Обрано оптимальну концентрацію 3-5 \% льняного шроту та шроту з насіння гарбуза в рецептурі булочок.

1. Капрельянц Л.В. Функиіональні продукти: монографія/ Л.В.Капрельяни, К.Г. Іоргачова.- Одеса: Друк, 2003.- 330С.

2. Дробот В.І. Технологія хлібопекарського виробництва / В.І. Дробот. - Київ : Логос, 2002. - 365 C.

3. Лакіза О.В. Особливості сучасного виробництва хлібобулочних виробів з додаванням продуктів переробки зерна кукурудзи / О.В. Лакіза, Л.В. Сидорчук // Хранение и переработка. - 2016. - № 12. - 52-53 С.

4. Зубар Н.М. Основи фізіологї̈ та гігієни харчуванняя/ Н.М. Зубар.-Київ : Центр учбової літератури, 2010. - 336 С. 
5. Шаповаленко О.І. Насіння різних сортів льону як компонент для виробництва комбікормів / О.І.Шаповаленко, О.Ю. Супрун-Крестова, О.С. Павлюченко // Хранение и переработка зерна. - 2008. - № 6. - С. 44-45.

6. Васильева А.Г. Химический состав и потенциальная биологическая иенность семян тыквы различных сортов / А.Г. Васильева, И.А. Круглова // Известия вузов. Пищевая технология. - 2007. - №5-6. - 31 С.

7. Дробот В.І. Лабораторний практикум технологї̈ хлібопекарського та макаронного виробництв: навч.посібник / B.I. Дробот. - К.: Центр навчальної літератури, 2006. - 341 C.

8. ГОСТ 24557-89. Изделия хлебобулочные сдобные. Технические условия. - Введ. 1990-07-01. - М.: ИПК Издательство стандартов, 2002. - 7 C.

9. ГОСТ 21094-75. Хлеб и хлебобулочные изделия. Метод определения влажности. - Введ. 1976-07-01. - М.: Стандартинформ, 2006. - 3 С.

10. ГОСТ 5669-96. Хлебобулочные изделия. Метод определения пористости. - Введ. 1996-04-12. - Минск: Межгосударственный совет по стандартизации, метрологии и сертификации, 1996. - 2 С.

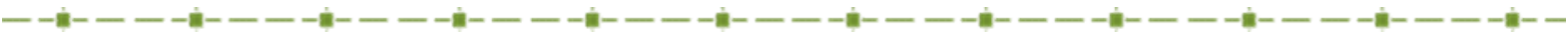 \\ Olga V. LAKIZA, Ph.D., Ass. Professor, Kateryna P. MASLIKOVA, Ph.D., Ass. Professor Mykola V. ISCHENKO, Master \\ Dnipro State Agrarian and Economic University \\ THE EFFICIENCY OF USING OF THE HIGH-PROTEIN FUNCTIONAL COMPONENTS IN THE PRODUCTION OF BUNS}

\section{Abstract}

Bakery products play a key role in the nutrition for most people in Ukraine. The demand for them is typical of people of any age, any social status and any level of income. The bakery sector should provide the consumers of the country with these vitally important food products in the necessary amount, assortment and quality.

In nowadays world, a lot of attention is paid to the enrichment of bakery products with various useful substances, which give them medicinal and preventive properties. The medicinal and preventive effect of using dietary bakery products is attained either by adding into the composition the necessary additional components, or by removing unwanted or changing the technology of their preparation. The search and use of new components of the compositions are considered to be one of the key conditions of the modern production of functional bakery products. Functional products are nutritive products that are a part of a normal diet, which, in addition to nutritional properties, have the ability to affect positively certain functions of the human body.

The modern directions of the expansion of the assortment of bakery products with the health - improving properties were considered. With the aim of the diversification of bakery produce of functional purpose, it was suggested to add the high-protein functional products to the composition of buns, namely flaxseed meal and pumpkinseed meal. It is known that flaxseed and pumpkinseed contain in their composition all essential amino acids.

Based on the carried out study, the composition of buns with the addition of flaxseed and pumpkinseed meals, which make it possible to obtain enriched buns of appropriate quality were developed. The organoleptic evaluation of buns with the different content of meals and the conclusion regarding their effect on the porosity and humidity of the finished products were made. Based on the new product's score the profilograms of enriched buns were built. The optimal concentration of flaxseed meal and pumpkinseed meal was chosen.

Key words: flaxseed meal, pumpkinseed meal, high-protein products, buns, organoleptic characteristics, humidity, porosity.

\section{REFERENCES}

1. Kaprel'janc L.V. Funkcional'ni produkty: monografija / L.V.Kaprel'janc, K.G. Iorgachova. - Odesa: Druk, 2003. - 330 S.

2. Drobot V.I. Tehnologija hlibopekars'kogo virobnyctva / V.I. Drobot. - Kï̈v : Logos, 2002. - 365 S.

3. Lakiza O.V. Osoblyvosti suchasnogo vyrobnyctva hlibobulochnyh vyrobiv z dodavannjam produktiv pererobky zerna kukurudzy / O.V. Lakiza, L.V. Sidorchuk// Hranenie i pererabotka zerna . - 2016. - № 12. - 52-53 S.

4. Zubar N.M. Osnovy fiziologii ta gigiiny harchuvannjaja / N.M. Zubar. - Kyiv : Centr uchbovoi literatury, 2010. - 336 S.

5. Shapovalenko O.I. Nasinnja riznih sortiv l'onu jak komponent dlja vyrobnictva kombikormiv / O.I.SHapovalenko, O.JU. Suprun-Krestova, O.S. Pavljuchenko // Hranenie i pererabotka zerna. - 2008. - № 6. - S. 44-45.

6. Vasil'eva A.G. Himicheskij sostav i potencial'naja biologicheskaja cennost' semjan tykvy razlichnyh sortov / A.G. Vasil'eva, I.A. Kruglova // Izvestija vuzov. Pishhevaja tehnologija. - 2007. - №5-6. - 31 S.

7. Drobot V.I. Laboratornij praktikum tehnologii hlibopekars'kogo ta makaronnogo vyrobnyctv: navch.posibnik / V.I. Drobot. - K.: Centr navchal'noi literatury, 2006. - 341 S.

8. GOST 24557-89. Izdelija hlebobulochnye sdobnye. Tehnicheskie uslovija. - Vved. 1990-07-01. - M.: IPK Izdatel'stvo standartov, 2002. - $7 \mathrm{~S}$.

9. GOST 5669-96. Hlebobulochnye izdelija. Metod opredelenija poristosti. - Vved. 1996-04-12. - Minsk: Mezhgosudarstvennyj sovet po standartizacii, metrologii i sertifikacii, 1996. - 2 S.

10. GOST 21094-75. Hleb $i$ hlebobulochnye izdelija. Metod opredelenija vlazhnosti. - Vved. 1976-07-01. - M.: Standartinform, 2006. $-3 S$.

Надійила 11.06.2018. До друку 22.06.2018 